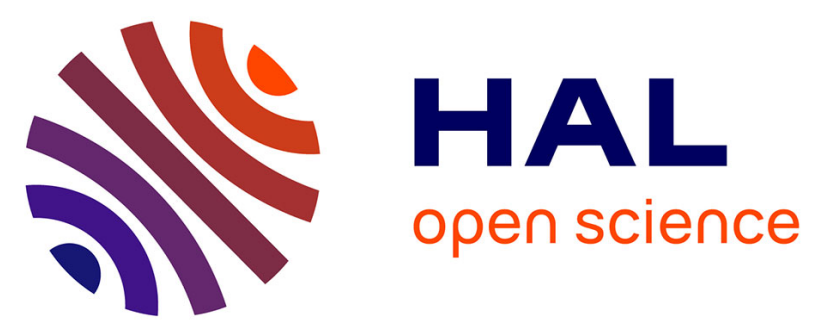

\title{
Pre- and syn-eruptive geochemistry of volcanic gases from Soufriere Hills of Montserrat, West Indies
}

G. Hammouya, P. Allard, P. Jean-Baptiste, F. Parello, M. Semet, S. Young

\section{To cite this version:}

G. Hammouya, P. Allard, P. Jean-Baptiste, F. Parello, M. Semet, et al.. Pre- and syn-eruptive geochemistry of volcanic gases from Soufriere Hills of Montserrat, West Indies. Geophysical Research Letters, 1998, 25 (19), pp.3685-3688. 10.1029/98GL02321 . hal-03119629

\section{HAL Id: hal-03119629 \\ https://hal.science/hal-03119629}

Submitted on 25 Jan 2021

HAL is a multi-disciplinary open access archive for the deposit and dissemination of scientific research documents, whether they are published or not. The documents may come from teaching and research institutions in France or abroad, or from public or private research centers.
L'archive ouverte pluridisciplinaire HAL, est destinée au dépôt et à la diffusion de documents scientifiques de niveau recherche, publiés ou non, émanant des établissements d'enseignement et de recherche français ou étrangers, des laboratoires publics ou privés. 


\title{
Pre- and syn-eruptive geochemistry of volcanic gases from Soufriere Hills of Montserrat, West Indies
}

\author{
G. Hammouya', P. Allard ${ }^{2}$, P. Jean-Baptiste ${ }^{2}$, F. Parello ${ }^{3}$, M.P. Semet ${ }^{4}$ and S.R. Young ${ }^{5}$
}

\begin{abstract}
Soufriere Hills fumaroles contained magmaderived volatiles before and during the eruption initiated in 1995 but also preserved a typical and quite steady hydrothermal composition. Chemical changes due to increased boiling and a greater input of oxidizing magmatic gas occurred only at Galway's Soufriere, the most active fumarolic field. Hydrothermal buffering of the fumaroles has been favoured by their remote location (1-2 km) from the eruptive vents and by a preferential degassing of the uprising magma through intrusive conduits under the crater. High temperature $\left(720^{\circ} \mathrm{C}\right)$ gas collected from the extruding lava dome in Feb. 1996 was chemically and isotopically representative of the magmatic gas stream. Its composition allows assessment of average eruptive fluxes of $\mathrm{H}_{2} \mathrm{O}, \mathrm{CO}_{2}$ and $\mathrm{HCl}$ which require the degassing of only 2.5-3 times more magma than erupted.
\end{abstract}

\section{Introduction}

Over its last centuries of dormancy Soufriere Hills (SFH) volcano has maintained an intense hydrothermal activity, with hundreds of steaming vents, mud pools and hot water discharges extending at $310-570 \mathrm{~m}$ a.s.l on its outer flanks, within four main fields: Galway's (GS), Gages Upper (GUS) and Lower (GLS), and Tar River (TRS) 'Soufrieres' (Fig. 1). These manifestations, linked to a high-enthalpy $\left(\approx 250^{\circ} \mathrm{C}\right)$ hydrothermal system [Chiodini et al., 1996], increased noticeably during intrusion-related seismic crises in 1933-37 [Perret, 1939], 1966-67 [Shepherd et al., 1971] and, then, before the current eruption. No manifestation existed inside the summit crater before phreatic vents suddenly opened there in July-August 1995, giving rise to extrusion of an andesitic lava dome since mid-November 1995 [Young et al., 1998].

Here we report and discuss chemical and isotopic data for SFH fumaroles, that were obtained before (up to 30 years ago) and during the current eruption, allowing assessment of precursory signals of the events. We also report unique results for a $720^{\circ} \mathrm{C}$ gas collected from the extruding lava dome. These help to characterize the local magmatic source and consitute the highest temperature datum ever obtained for a volcanic fluid in the Lesser Antilles Arc.

'G. Hammouya, Observatoire volcanologique de la Soufriere, IPG, Le Houëlmont, 97113 Gourbeyre, Guadeloupe, French W. Indies.

${ }^{2} P$. Allard and P. Jean-Baptiste, LSCE, CEA-CNRS, 91190 Gif/Yvette, France (e-mail: allard@isce.saclay.cea.fr).

${ }^{3}$ F. Parello, CFTA, Università di Palermo, via Archiraffi 36, 90123 , Palermo, Italy (e-mail: parello@mbox.unipa.it).

${ }^{4}$ M.P. Semet, LGSC. IPGP, 4 place Jussieu, 75252 Paris cedex 05, France (semet(a)ipgp.jussieu.fr)

'S.R. Young, British Geological Survey, Murchison House, West Mains Road, Edinburgh EH9 3LA, U.K. (e-mail: sry@bgs.ac.uk).

Copyright 1998 by the American Geophysical Union.

Paper number 98GL02321.

0094-8534/98/98GL-02321\$05.00

\section{Geochemical Evolution of Fumaroles}

SFH fumaroles were early studied by Perret (1939), but their first quantitative analysis dates from the 1966-67 seismic crisis (M. Chaigneau, unpub. data; Table). Sparse data were further gathered in 1985-1989 [IPG Observ. Guadeloupe, unpub.] and, for geothermal exploration, in 1991-92 [Chiodini et al., 1996]. Stimulated by increasing pre-eruptive seismicity, a fumarole survey was started in March 1995 and was then intensified after the eruption onset [Hammouya et al., 1996], through a collaboration between MVO (Montserrat Volcano Observatory) and the Soufriere Observatory in Guadeloupe (where routine chemical analysis was operated). This survey lasted until pyroclastic flows threatened the fumarolic areas, all of which were progressively burried or destroyed. This enhances the interest of the results obtained, despite their sparsity and/or incompletness for some species $\left(\mathrm{H}_{2} \mathrm{O}, \mathrm{CO}\right.$ and $\left.\mathrm{He}\right)$. The largest dataset is for Galway's Soufriere, the most accessible but most active field. More discrete results were obtained at other sites. The Table reports analyses for each field at representative dates, together with isotopic results for $\mathrm{He}$ and $\mathrm{C}$. The following features can be outlined:

(1) Over the whole period investigated SFH fumaroles kept steady surface boiling temperatures of $96-98^{\circ} \mathrm{C}$ and a typical hydrothermal chemistry. $\mathrm{H}_{2} \mathrm{O}(91-97 \%), \mathrm{CO}_{2}$ and $\mathrm{H}_{2} \mathrm{~S}$ were the dominant species, coexisting with minor amounts of $\mathrm{H}_{2}, \mathrm{CH}_{4}$ and $\mathrm{CO}$. Air contamination was broadly low. $\mathrm{H}_{2} \mathrm{~S}$ was always very abundant, but $\mathrm{SO}_{2}$ and $\mathrm{HCl}$, which are typical components of magmatic gases, were never detected.

(2) He and C isotopic data obtained before (since 1992) and during the eruption however demonstrate a MORB-type magmatic derivation of helium and carbon dioxide emitted from GS, TRS and, to a lesser extent, GLS (Table). Particularly, both in March 1995 and February 1996 GS fumaroles had

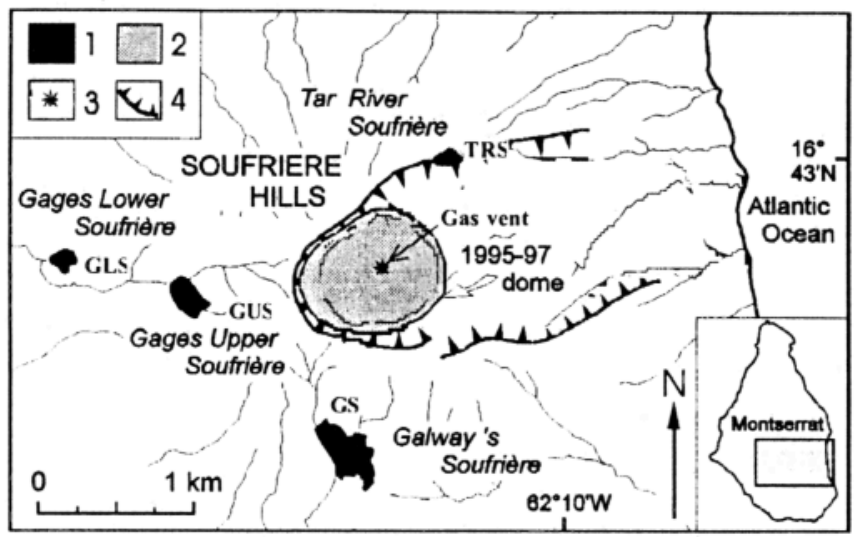

Figure 1. Map of Soufriere Hills showing 1: the fumarolic fields; 2: the 1995-97 lava dome, covering former Castle Peak dome (dashed contour); 3: the site of dome gas sampling (Feb. 1996); and 4: English's Crater rim. 
Table. Chemical and Isotopic Composition of Fumarolic and Magmatic fluids of Soufriere Hills Volcano, Montserrat

\begin{tabular}{|c|c|c|c|c|c|c|c|c|c|c|c|c|c|c|c|c|}
\hline Site & Date & $\mathrm{T}^{\circ} \mathrm{C}$ & $\begin{array}{r}\mathrm{H}_{2} \mathrm{O} \\
\% \text { tot. }\end{array}$ & $\begin{array}{c}\mathrm{CO}_{2} \\
\% \\
\end{array}$ & $\begin{array}{c}\mathrm{H}_{2} \mathrm{~S} \\
\% \\
\end{array}$ & $\begin{array}{c}\mathrm{SO}_{2} \\
\% \\
\end{array}$ & $\begin{array}{r}\mathrm{H}_{2} \\
\% \\
\end{array}$ & $\begin{array}{c}\mathrm{CH}_{4} \\
\% \\
\end{array}$ & $\begin{array}{l}\mathrm{CO} \\
\mathrm{ppm}\end{array}$ & $\begin{array}{l}\mathrm{N}_{2} \\
\% \\
\end{array}$ & $\begin{array}{l}\mathrm{O}_{2} \\
\% \\
\end{array}$ & $\begin{array}{l}\mathrm{He} \\
\mathrm{ppm}\end{array}$ & $\begin{array}{c}\mathrm{HCl} \\
\% \\
\end{array}$ & $\mathrm{~S} / \mathrm{C}$ & $\begin{array}{c}{ }^{3} \mathrm{He}{ }^{4} \mathrm{He} \\
\mathrm{R} / \mathrm{R}_{\mathrm{a}}\end{array}$ & $\begin{array}{c}\delta^{13} \mathrm{C} \\
\% 0 \\
\end{array}$ \\
\hline $\begin{array}{l}\text { Galways' } \\
\text { Galways' }^{\prime} \\
\text { Galways } \\
\text { Galways } \\
\text { Galways } \\
\text { Galways } \\
\text { Galways }\end{array}$ & $\begin{array}{r}15 / 07 / 66 \\
23 / 09 / 67 \\
03 / 91 \\
09 / 92 \\
16 / 03 / 95 \\
11 / 07 / 95 \\
02 / 08 / 95 \\
22 / 11 / 95 \\
27 / 02 / 96 \\
04 / 06 / 96\end{array}$ & $\begin{array}{l}98 \\
98 \\
98 \\
98 \\
98 \\
98.4 \\
98.0 \\
96.2 \\
96.7 \\
98.0\end{array}$ & $\begin{array}{l}92.9 \\
92.2 \\
93.4\end{array}$ & $\begin{array}{l}72.8 \\
70.0 \\
74.1 \\
71.7 \\
69.5 \\
68.4\end{array}$ & $\begin{array}{l}25.6 \\
28.9 \\
25.3 \\
27.4 \\
30.0 \\
30.3 \\
33.6 \\
36.0 \\
37.9 \\
39.6\end{array}$ & $\begin{array}{l}0 \\
0 \\
0 \\
0 \\
0 \\
0 \\
0 \\
0 \\
0 \\
0\end{array}$ & $\begin{array}{l}0.02 \\
0.20 \\
0.21 \\
0.096 \\
0.005 \\
0.012 \\
0.004 \\
0.006 \\
0.013 \\
0.045\end{array}$ & $\begin{array}{l}0.04 \\
0.10 \\
0.024 \\
0.037 \\
0.02 \\
0.012 \\
0.015 \\
0.039 \\
0.043 \\
0.054\end{array}$ & $\begin{array}{c}0 \\
0 \\
2.2 \\
0.4 \\
\\
0 \\
0 \\
0 \\
7.3 \\
0\end{array}$ & $\begin{array}{l}2.5 \\
0.6 \\
0.9 \\
0.4 \\
0.6 \\
1.1 \\
1.7 \\
1.4 \\
1.1 \\
1.2\end{array}$ & $\begin{array}{l}0.13 \\
0.22 \\
0.34 \\
0.32 \\
0.25 \\
0.39\end{array}$ & $\begin{array}{r}5.9 \\
6.3 \\
16.7\end{array}$ & $\begin{array}{l}0 \\
0 \\
0 \\
0 \\
0 \\
0 \\
0 \\
0 \\
0 \\
0\end{array}$ & $\begin{array}{l}0.35 \\
0.41 \\
0.34 \\
0.38 \\
0.43 \\
0.44 \\
0.52 \\
0.58 \\
0.62 \\
0.67\end{array}$ & 2) & -5.6 \\
\hline $\begin{array}{l}\text { Tar River } \\
\text { Tar River }^{2} \\
\text { Tar River } \\
\text { Tar River } \\
\text { Tar River } \\
\text { Tar River }\end{array}$ & $\begin{array}{c}27 / 05 / 89 \\
03 / 91 \\
16 / 03 / 95 \\
12 / 07 / 95 \\
14 / 11 / 95 \\
28 / 02 / 96\end{array}$ & $\begin{array}{l}98 \\
98 \\
97.1 \\
97.2 \\
96.7 \\
98.0\end{array}$ & $\begin{array}{l}96.6 \\
95.5\end{array}$ & $\begin{array}{l}19.4 \\
77.3 \\
77.9 \\
79.2\end{array}$ & $\begin{array}{l}15.8 \\
17.6 \\
16.2 \\
19.9 \\
19.3 \\
17.3\end{array}$ & $\begin{array}{l}0 \\
0 \\
0 \\
0 \\
0 \\
0\end{array}$ & $\begin{array}{l}0.08 \\
0.091 \\
0.082 \\
0.085 \\
0.08 \\
0.092\end{array}$ & $\begin{array}{l}0.20 \\
0.08 \\
0.09 \\
0.08 \\
0.11 \\
0.11\end{array}$ & $\begin{array}{l}0 \\
0.6 \\
1.2 \\
0 \\
0 \\
0\end{array}$ & $\begin{array}{l}1.2 \\
1.3 \\
3.4 \\
2.2 \\
2.2 \\
2.8\end{array}$ & $\begin{array}{l}0.89 \\
0.44 \\
0.48 \\
0.65\end{array}$ & $\begin{array}{l}7.3 \\
9.0\end{array}$ & $\begin{array}{l}0 \\
0 \\
0 \\
0 \\
0 \\
0\end{array}$ & $\begin{array}{l}0.19 \\
0.22 \\
0.20 \\
0.26 \\
0.25 \\
0.22\end{array}$ & $7.9(7.9)$ & -4.5 \\
\hline $\begin{array}{l}\text { Upper Gages } \\
\text { Upper Gages } \\
\text { Upper Gages } \\
\text { Upper Gages }\end{array}$ & $\begin{array}{r}23 / 09 / 67 \\
03 / 91 \\
09 / 92 \\
27 / 07 / 95\end{array}$ & $\begin{array}{l}98 \\
98 \\
98 \\
97.8\end{array}$ & $\begin{array}{l}95.6 \\
96.5\end{array}$ & $\begin{array}{l}80.6 \\
87.0 \\
86.6 \\
83.0\end{array}$ & $\begin{array}{l}16.1 \\
11.6 \\
11.1 \\
14.6\end{array}$ & $\begin{array}{l}0 \\
0 \\
0 \\
0\end{array}$ & $\begin{array}{l}0.60 \\
0.49 \\
0.43 \\
0.35\end{array}$ & $\begin{array}{l}0.30 \\
0.43 \\
0.43 \\
0.31\end{array}$ & $\begin{array}{c}2000^{\&} \\
0.6 \\
0.5 \\
0\end{array}$ & $\begin{array}{l}2.1 \\
1.3 \\
0.7 \\
1.4\end{array}$ & 0.33 & $\begin{array}{l}4.5 \\
4.3\end{array}$ & $\begin{array}{l}0 \\
0 \\
0 \\
0\end{array}$ & $\begin{array}{l}0.20 \\
0.13 \\
0.13 \\
0.17\end{array}$ & & \\
\hline $\begin{array}{l}\text { Lower Gages }^{2} \\
\text { Lower Gages }^{2} \\
\text { Lower Gages } \\
\text { Lower Gages }\end{array}$ & $\begin{array}{r}03 / 91 \\
09 / 92 \\
27 / 02 / 96 \\
07 / 04 / 97\end{array}$ & $\begin{array}{l}99 \\
99 \\
96.4 \\
97\end{array}$ & $\begin{array}{l}95.2 \\
96.4 \\
96.0\end{array}$ & $\begin{array}{l}91.2 \\
91.9 \\
83.2 \\
66.0\end{array}$ & $\begin{array}{r}7.7 \\
6.9 \\
11.3 \\
7.6\end{array}$ & $\begin{array}{l}0 \\
0 \\
0 \\
0\end{array}$ & $\begin{array}{l}011 \\
0.096 \\
0.09\end{array}$ & $\begin{array}{l}0.62 \\
0.51 \\
0.55 \\
0.36\end{array}$ & $\begin{array}{c}0.6 \\
0.4 \\
0 \\
0\end{array}$ & $\begin{array}{r}0.8 \\
0.9 \\
3.9 \\
19.8\end{array}$ & $\begin{array}{l}0.90 \\
5.5\end{array}$ & $\begin{array}{r}6.2 \\
6.1 \\
16.4\end{array}$ & $\begin{array}{l}0 \\
0 \\
0 \\
0\end{array}$ & $\begin{array}{l}0.07 \\
0.13 \\
0.11\end{array}$ & $\begin{array}{l}5.9(5.9) \\
6.3(6.4)\end{array}$ & -3.1 \\
\hline $\begin{array}{l}\text { Lava dome } \$ \\
\text { Lava dome } \\
\text { Lava dome } \\
\text { Lava dome edge }\end{array}$ & $\begin{array}{l}27 / 02 / 96 \\
27 / 02 / 96 \\
27 / 02 / 96 \\
e^{\prime \prime}\end{array}$ & $\begin{array}{l}720 \\
720 \\
720 \\
150\end{array}$ & $\begin{array}{l}90.3^{*} \\
91.8^{*}\end{array}$ & $\begin{array}{r}19.4 \\
15.1 \\
1.8\end{array}$ & $\begin{array}{l}0 \\
0\end{array}$ & $\Sigma \mathbf{S})$ & $\begin{array}{l}4.11 \\
3.64 \\
1.29\end{array}$ & $\begin{array}{l}0.19 \\
0.49 \\
0.18\end{array}$ & $\begin{array}{l}647 \\
598\end{array}$ & $\begin{array}{l}46.7 \\
65.5 \\
76.8\end{array}$ & $\begin{array}{r}9.6 \\
15.1 \\
19.5\end{array}$ & $\begin{array}{l}4.2 \\
<5\end{array}$ & 16.7 & $\begin{array}{l}0.26 \\
0.28\end{array}$ & 7.7) & $\begin{array}{l}-5.9 \\
-5.2\end{array}$ \\
\hline
\end{tabular}

$\mathrm{H}_{2} \mathrm{O}$ in vol. \% of total fluid, other components referred to the anhydrous gas phase (0 values: below detection; blanks: not determined). Data from: ${ }^{1} \mathrm{M}$. Chaigneau (CNRS, unpub., quadrupole mass spectrometry): ${ }^{2}$ Chiodini et al., 1996 (gas chromatography); and this work (gas chromatography, plus acidımetric titration $\left(\mathrm{CO}_{2}\right)$ and electrochemistry (total $\mathrm{S}$ and $\mathrm{Cl}$ ) in case of lava dome gas sampled through soda solution ${ }^{\mathrm{s}}$ ). ${ }^{+} \mathrm{H}_{2} \mathrm{O}$ without air contamination. ${ }^{8}$ Uncertain value. Gas sampling in pre-evacuated glass bottles or/and in copper tubes (for He isotopes). ${ }^{3} \mathrm{He} /{ }^{4} \mathrm{He}$ ratios $( \pm 0.3 \%$ ) are normalized to the atmospheric ratio $\left(\mathrm{R}_{\mathrm{a}}=1.38 \times 10^{-6}\right)$; values in brackets were corrected for air dilution based on sample's content in $\mathrm{Ne}$ [Chiodini et al., 1996] or $\mathrm{N}_{2}$ (this work). $\delta^{i !} \mathrm{C}$ values $( \pm 0.1 \%)$ vs. PDB standard.

${ }^{3} \mathrm{He} /{ }^{4} \mathrm{He}$ ratio $\left(7.5-7.9 \mathrm{R}_{3}\right)$ and $\delta^{13} \mathrm{C}$ values $(-5.3$ to $-5.6 \%$ ) very close to those found for the lava dome gas $\left(7.7 \mathrm{R}_{\mathrm{a}}\right.$ and $-5.9 \%$ ). These isotopic data thus evidence a pre- and syn-eruptive magmatic contribution to SFH fumaroles, whose otherwise peristent hydrothermal signature requires the buffering by thermal aquifers. These data also suggest a magmatic origin of the abundant sulfur, $\mathrm{SO}_{2}$ being readily converted to $\mathrm{H}_{2} \mathrm{~S}$ during water-gas-rock interactions [Giggenbach, 1987] and any associated $\mathrm{HCl}$ removed in aqueous solutions.

(3) Minor temporal variations were detected in GUS, GLS and TRS fumaroles (Fig. 2), whose compositional range can be ascribed to a different degree (or depth) of boiling of a single aquifer (curve in Fig. 2a) or interacting aquifers (Fig. 2b). In contrast, significant changes occurred in GS fumaroles, whose feeding source was clearly distinct. These changes included (Fig. 3): i) Smooth anticorrelated variations of $\mathrm{S} / \mathrm{C}$ and $\mathrm{H}_{2} / \mathrm{CO}_{2}$ ratios from 1988 to mid-1995, with a tendency to higher sulfur and lower $\mathrm{H}_{2}$ (also vs. $\mathrm{CH}_{4}$ ) during pre-eruptive seismicity; ii) Sharp oscillations of the same ratios (with strong $\mathrm{H}_{2}$ spikes, e.g. August 11,1995$)$ during the phreatic events; then iii) a marked increase of sulfur (S/C), $\mathrm{CO}$ and $\mathrm{He}$ (Table), but low $\mathrm{H}_{2}$ during dome growth. A concomittant rise of He occurred at TRS and GLS, but with opposite trend in ${ }^{3} \mathrm{He} /{ }^{4} \mathrm{He}$.

(4) Assuming a redox control of $\mathrm{CH}_{4} / \mathrm{CO} / \mathrm{CO}_{2}$ ratios in the fumaroles by vapour-rock exchanges at depth [Giggenbach, 1987], we infer an equilibrium temperature of up to $272^{\circ} \mathrm{C}$ for GS fluids in 1996 , compared to steady values of $161-201^{\circ} \mathrm{C}$ at other sites (Fig. 4). Taking account of gas solubilities in water at such temperatures $\left(\mathrm{H}_{2} \approx \mathrm{CH}_{4} \ll \mathrm{CO}_{2}<\mathrm{H}_{2} \mathrm{~S}\right)$, increased boiling beneath GS could simply account for the anticorrelated variations of $\mathrm{S} / \mathrm{C}$ and $\mathrm{H}_{2} / \mathrm{CO}_{2}$ before the eruption. But this process alone cannot explain the large variations of $\mathrm{H}_{2}$ vs. $\mathrm{CH}_{4}$ before and during the phreatic events (Fig. $2 \mathrm{~b}$ and 3 ), nor the synchronous rise of $\mathrm{S} / \mathrm{C}$ and poorly soluble $\mathrm{He}$ and $\mathrm{CO}$ during dome growth. These trends suggest a greater inflow of $\mathrm{SO}_{2}$-rich, comparatively oxidizing magmatic gas that affected the redox conditions of the aquifer, to which $\mathrm{H}_{2}$ is much faster to adjust than $\mathrm{CH}_{4}$ [Giggenbach, 1987].

\section{Geochemistry of Lava Dome Gas}

On February 27, 1996, just before the first pyroclastic flows, two of us (G.H. and P.A.) could briefly sample gas exhaled at $720^{\circ} \mathrm{C}$ from an incandescent fracture in the extruding lava dome (Table). This gas was strongly diluted and partly oxidized by air circulating among the lava blocks, but differed markedly from the fumaroles in containing $\mathrm{SO}_{2}, \mathrm{HCl}$ and high amounts of $\mathrm{H}_{2}$ and $\mathrm{CO}$. Its $\mathrm{CO} / \mathrm{CO}_{2}-\mathrm{H}_{2} / \mathrm{H}_{2} \mathrm{O}$ ratios suggest an equilibrium oxygen fugacity close to both $\mathrm{NNO}$ and the $\mathrm{H}_{2} \mathrm{~S}$ $\mathrm{SO}_{2}$ buffers at $720^{\circ} \mathrm{C}$ (Fig. 4), somewhat lower than expected for a gas equilibrated with molten $\mathrm{SFH}$ andesite at $850^{\circ} \mathrm{C}$ $(\mathrm{NNO}+1( \pm 0.5) ; \quad$ Barclay et al., 1998]). Such a shift is attributed to secondary alterations during our sampling, also responsible for excessive methane (see Fig. 4). 

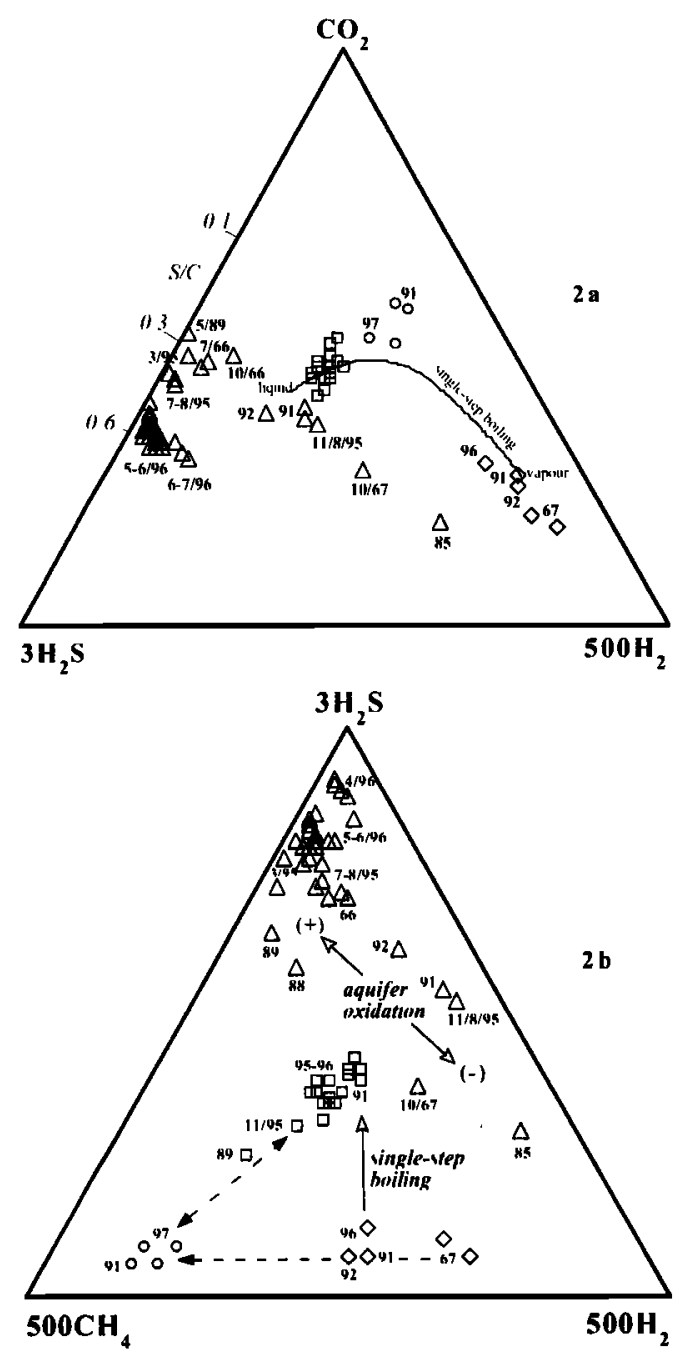

Figure 2. Triangular plots of $\mathrm{CO}_{2}-\mathrm{H}_{2} \mathrm{~S}-\mathrm{H}_{2}-\mathrm{CH}_{4}$ in Soufriere Hills fumaroles, 1966-1997: GS (triangles), TRS (squares), GUS (diamonds) and GLS (circles). 2a) Curve: $\mathrm{CO}_{2}-\mathrm{H}_{2} \mathrm{~S}-\mathrm{H}_{2}$ evolution during single-step boiling of a $\sim 250^{\circ} \mathrm{C}$ aquifer with initial vapour phase similar to GUS samples [Chiodini et al., 1996]. 2b) GUS and TRS data points also defines mixing trends with a $\mathrm{CH}_{4}$-rich GS-type fluid, at constant $\mathrm{H}_{2} / \mathrm{H}_{2} \mathrm{~S}$ ratio. Owing to similar solubility behaviour of $\mathrm{H}_{2}$ and $\mathrm{CH}_{4}$, the large variations of $\mathrm{H}_{2} / \mathrm{CH}_{4}$ at $\mathrm{GS}$ cannot be due to boiling and, rather, suggest changing redox conditions in the aquifer, due to the input of more oxidizing magmatic gas. See text.

The high water content of the dome gas is typical of andesitic magmatic fluids in subduction zones [e.g. Allard, 1983]. In contrast, its greater richness in chlorine than sulfur $(\mathrm{Cl} / \mathrm{S} \approx 4)$ is a rarer feature, encountered at a few arc volcanoes in post-eruptive rather than eruptive stage (e.g. Showa-Shinzan, in Japan; [Symonds et al., 1996]). A high $\mathrm{Cl} / \mathrm{S}$ ratio was however measured both in the volcanic plume [Allen. 1996; Oppenheimer et al., 1998] and in crystal melt inclusions of SFH andesite [Hammouya et al., 1996; Young et al., 1998] and is thus characteristic of eruptive degassing at Soufriere Hills.

An average $\mathrm{SO}_{2}$ flux of ca. 400 tons per day, equivalent to ca. $0.3 \mathrm{~kg}$ of $\mathrm{S}$ per ton of extruded magma $(0.03 \mathrm{wt} \%)$, was emitted during dome growth in 1995-1997 [Young et al., 1998]. Combining these numbers with the dome gas composition allows us to assess contemporaneous fluxes of ca. 900, 1400 and 25000 t.d $\mathrm{d}^{-1}$ of $\mathrm{HCl}, \mathrm{CO}_{2}$ and $\mathrm{H}_{2} \mathrm{O}$, respectively, supplied by a loss of $0.13,0.21$ and $3.7 \mathrm{wt} \%$ of

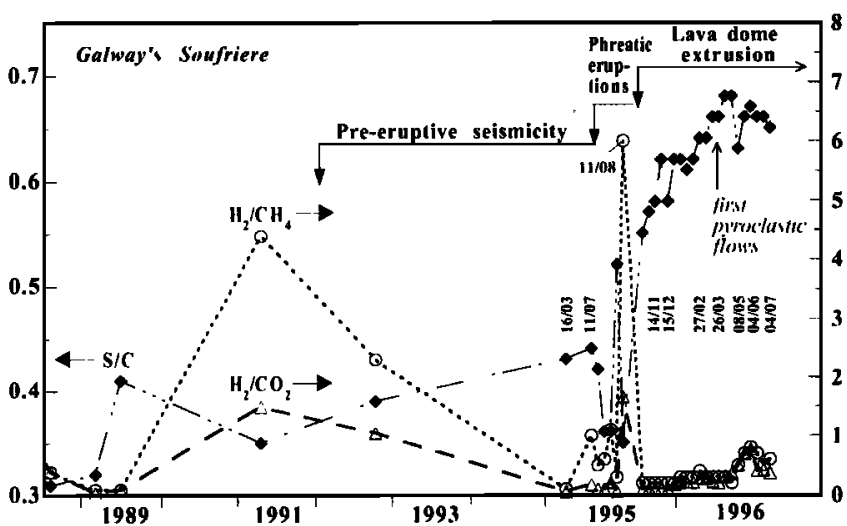

Figure 3. Pre- and syn-eruptive variations of $\mathrm{S} / \mathrm{C}, \mathrm{H}_{2} / \mathrm{CO}_{2}$ $\left(\times 10^{7}\right)$ and $\mathrm{H}_{2} / \mathrm{CH}_{4}$ ratios in GS fumaroles (time scale $\times 2$ for 1995 and 1996). All analyses made with gas chromatography.

each same species from the extruded magma. The weight losses for $\mathrm{HCl}$ and $\mathrm{H}_{2} \mathrm{O}$ compare fairly well with those derived from their respective abundances in crystal melt inclusions and degassed glass in the andesite (0.1-0.2 and 3.5-4.0 wt \%; [Young et al., 1998; Barclay et al., 1998]). This supports a magmatic origin of $\mathrm{H}_{2} \mathrm{O}$ and minor hydrothermal addition to the volcanic plume. Now, for an original melt fraction of $40 \%$ in the andesite [Devine et al., 1998], the above volatile fluxes require the degassing of 2.5-3 times more magma than was erupted. Such a degassing excess, also verified for sulfur

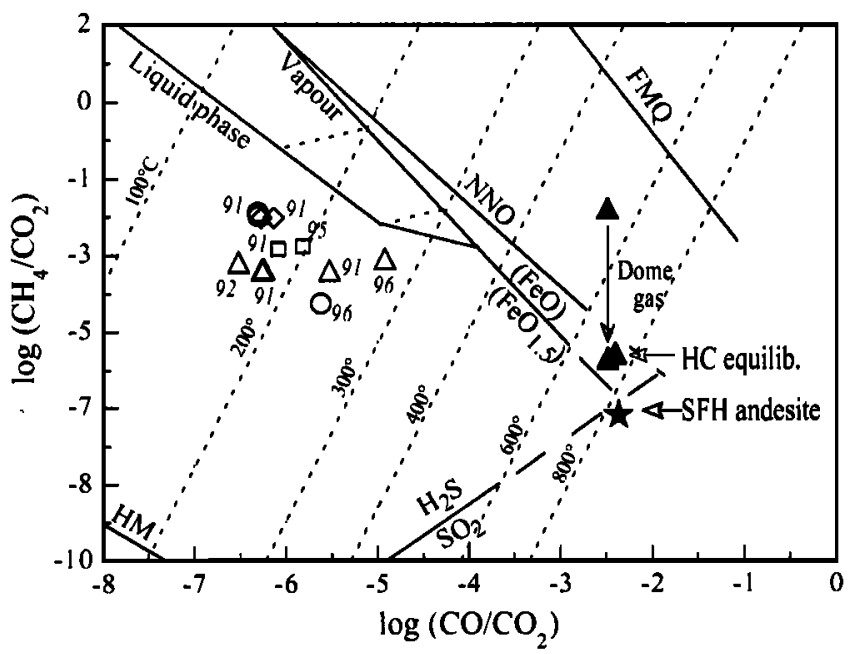

Figure 4. $\mathrm{CH}_{4} / \mathrm{CO}_{2}$ vs $\mathrm{CO} / \mathrm{CO}_{2}$ in $\mathrm{SFH}$ fumaroles, dissolved gas in GS thermal water (dotted circle) and lava dome gas (dark triangles), with respect to mineral and $\left(\mathrm{H}_{2} \mathrm{~S}_{-} \mathrm{SO}_{2}\right)$ redox buffers (modified from Giggenbach, 1987). FMQ: fayalite-magnetitequartz; NNO: nickel-nickel oxide; HM: hematite-magnetite. Isotherms refer to redox equilibrium buffered by vapour-rock exchange. All fumaroles plot below the rock-buffered liquidvapour domain typical for common hydrothermal systems, i.e. towards more oxyding (magmatic) conditions, with inferred equilibrium temperatures ranging from $161^{\circ} \mathrm{C}$ (GLS) to $272^{\circ} \mathrm{C}$ (GS). 'HC': equilibrium composition of the dome gas at $720^{\circ} \mathrm{C}$ and $\log f \mathrm{O}_{2}=-15.77$, as computed from its measured $\mathrm{CO} / \mathrm{CO}_{2}$ ratio (thermodynamic data from Giggenbach, 1987). Excessive methane $\left(\mathrm{CH}_{4} / \mathrm{CO}_{2}\right.$ ratio) in samples is due to a pollution from burning of our silicone tight upon sampling. Star: theoretical plot for a gas equilibrated with SFH andesite magma in the P-T redox conditions of its reservoir $\left(\sim \mathrm{NNO}+1\right.$ at $850^{\circ} \mathrm{C}$ and $\mathrm{P}_{\mathrm{H} 2 \mathrm{O}}$ of 110-130 MPa; Barclay et al., 1998). 
[Young et al., 1998], is quite small compared to that observed at other erupting arc volcanoes [e.g. Andres et al., 1991; Allard et al., 1994]. It suggests a moderate gas saturation of SFH magma prior to eruptive ascent from its storage system.

\section{Discussion and Conclusions}

The data reported here and those for thermal waters in Montserrat [Chiodini et al., 1996] strongly suggest that hydrothermal activity at Soufriere Hills has long been sustained by a deep supply of magmatic heat and gas to the overlying aquifers. This is supported by ${ }^{3} \mathrm{He} /{ }^{4} \mathrm{He}$ data (we also found a ratio of $5 R_{d}$ in gas bubbling through Hot Pond thermal springs, along the northern coast, in March 1995) and by the position of all SFH fumaroles in Figure 4; these plot below the rock $\left(\mathrm{FeO}-\mathrm{FeO}_{15}\right)$ buffered vapour-liquid domain typical of most hydrothermal systems [Giggenbach, 1987], i.e. towards more oxidized (magmatic) redox conditions.

The growth of fumarolic activity during previous noneruptive intrusions and before the current eruption points to an increase of this supply due to magma ascent and decompression. Now, the minor chemical changes in most fumaroles in 1995-96, their preservation of typical hydrothermal features, and the lack of any phreatic eruption (i.e. of excess gas loading) in all fumarolic areas imply that degassing of the uprising magma has preferentially been forced through central intrusive conduits under the crater. This is consistent with evidence of extensive sealing of the magma conduit walls [Boudon et al., 1998] and with the peripheral confinement of all fumarolic manifestations at remote distance (1-2 km) from the eruptive vents (Fig. 1). Such conditions were favourable to hydrothermal buffering.

Fumaroles at Galway's Soufriere have been more sensitive to the magmatic input, even though their ${ }^{3} \mathrm{He} /{ }^{4} \mathrm{He}$ ratio was not the highest measured one. From 1967 to 1992 their composition ( $\mathrm{S} / \mathrm{C}$ ratio) remained quite unchanged (Fig. 2a), excepting a great variability in minor $\mathrm{H}_{2}$, partly due to uncertainty on pre-1988 analyses by mass spectrometry. Their evolution before and during the phreatic events in 1995 point to increasing disturbance of their feeding aquifer as the magma was approaching the surface, fracturing the volcanic pile. While gas-rich aqueous solutions could gain a temporary access to the central conduit zone before being blasted out at the crater (we measured $12 \mathrm{~g} / \mathrm{kg}$ of $\mathrm{Cl}$ in a plume condensate from the July 28, 1995 phreatic eruption, compared to $26 \mathrm{~g} / \mathrm{kg}$ in dome gas), more reduced hydrothermal fluids were occasionally entrained beneath GS, leading to the sharp $\mathrm{H}_{2} / \mathrm{CH}_{4}$ spikes superimposed on a longer trend of decreasing $\mathrm{H}_{2}$ attributed to greater aquifer boiling and oxidation. Enhanced water-rock interactions and mixing with fluids richer in helıum but poorer in ${ }^{3} \mathrm{He}$ is also suggested by the lowering of ${ }^{3} \mathrm{He} /{ }^{4} \mathrm{He}$ at both GS and TRS (note, however, that ${ }^{3} \mathrm{He} /{ }^{4} \mathrm{He}$ ratio at all sites gradually converged towards the dome gas ratio). The system reached a more steady regime when magma extrusion and degassing developped through the open vents, with a possible reversed evolution of S/C at GS in June 1996 (Fig. 3).

This work further outlines that, whenever possible, geochemical monitoring of comparable dormant volcanoes must be done on fumaroles the closest to magma conduits, where independent gas columns can rise through aquifers and, thus, bring less filtered indication of eruptive potential.
Acknowlegements. We acknowledge the support of MVO staff and contributions to gas sampling by J. Daley and G. Gray (Montserrat Forest Service), G. Norton and G. Skerritt (MVO), J. Battaglia and J.C. Komorowski (IPG). C. Federico and A. Dapoigny helped to He isotopic analysis. Partial funding was due to CNRS (INSU-PNRN, RV12). Published by permission of Director, British Geological Survey (NERC).

Two anonymous referees helped us in improving our manuscript.

\section{References}

Allard, P., The origin of water, carbon, sulfur, nitrogen and rare gases in volcanic exhalations: evidence from isotope gcochemistry, in Forecasting Volcanic Events, edited by H. Tazieff and J.C. Sabroux, Elsevier, Amsterdam, pp. 337-386, 1983.

Allard, P.. J. Carbonnelle, N. Métrich, H. Loyer and P. Zettwoog. Sulphur output and magma degassing budget of Stromboli volcano, Nature, 368, 326-330, 1994

Allen, A.G., The influence of local volcanic emissions on the atmospheric environment of Montserrat, West Indies, Abstract. Applied Geoscience 96. Warwick, April, 1996.

Andres, R.J., W. Rose, P.R. Kyle, S. de Silva, P. Francıs, M. Gardeweg and R.H. Moreno, Excessive sulphur dioxide emissions from Chilean volcanoes. J Volcan. Geotherm. Res., 46, 323-329, 1991.

Barclay, I., M.J. Rutherford, M.R. Caroll, M.D. Murphy, J.D. Devine, J. Gardner and R.S.J. Sparks, Experimental phase equilibria constraints on pre-eruptive storage conditions of the Soufriere Hills magma, Geophvs. Res. Lett., this issue, 1998.

Boudon, G., B. Villemant, J.C. Komorowski, P. Ildefonse and M.P. Semet, Characterization of the hydrothermal system of Soufriere Hills volcano, Montserrat (West Indies): implications for renewal of activity since 1995, Geophys Res. Lett., this issue, 1998.

Chiodini, G. , R. Cioni, A. Frullanı, M. Guidi, L. Marini, F. Prati and B. Raco, Fluid geochemistry of Montserrat Island, West Indies, Bull. Volcanol., 58, 380-392, 1996.

Devine, J.D., M.D. Murphy, M.J. Rutherford, J. Barclay, R.S.J. Sparks, M R Caroll, S R. Young and J.E. Gardner, Petrological evidence for pre-eruptive pressure-temperature conditions, and recent reheating, of andesite magma erupting at Soufriere Hills volcano, Montserrat, W.I., Geophvs. Res. Lett., this issue, 1998.

Giggenbach, W.F.. Geothermal gas equilibria, Geochim Cosmochim Acta, 44, 2021-2032, 1980.

Giggenbach, W.F., Redox processes governing the chemistry of fumarolic gas discharges from White Island, New Zealand, $A p p l$. Geochem., 2, 143-161, 1987.

Harnmouya, G., P. Allard, R. Clocchiatti, P. Jean-Baptiste, F. Parello and M.P. Semet, Geochemistry of fumarolic and magmatic fluids from Soufriere Hills volcano, Montserrat: preliminary observations (abstract), 2nd Carribean Conf. on Natural Hazards and Disasters, Univ. of West Indies, Jamaica, October 9-12, 1996.

Oppenheimer, C.M., P. Francis and A. Maciejewski, Spectroscopic observations of $\mathrm{HCl}$ degassing from Soufriere Hills volcano, Montserrat, Geophys. Res. Lett., this issue, 1998.

Perret, F., The volcanic-seismic crisis at Montserrat 1933-1937, $75 \mathrm{pp}$., Carnegie Institution of Washington, $n^{\circ} 512$, Washington D.C., 1939.

Shepherd, J.B., J.F. Tomblin and D.F. Wood, Volcanoseismic crisis in Montserrat, West Indies, 1966-67, Bull. Volcanol., 35, 143-163, 1971.

Symonds, R.B., Y. Mizutani and P.H. Briggs, Long-term geochemical surveillance of fumaroles at Showa-Shinzan dome, Usu volcano, Japan, J. Volcan. Geotherm. Res., 73, 177-211, 1996.

Young, S.R., R. Robertson, L. Lynch, A.D. Miller, W.A. Ambeh, W. Aspinall, J.B. Shepherd, R.S.J. Sparks and MVO staff, Overview of the current eruption of the Soufriere Hills Volcano, Geophys. Res. Lett., this issue, 1998.

Young, S.R., et al., Monitoring sulphur dioxide emission at the Soufriere Hills volcano: implications for changes in eruptive conditions, Geophys. Res. Lett., this issue, 1998.

(Received April 6, 1998; revised May 26, 1998; accepted June 22, 1998.) 